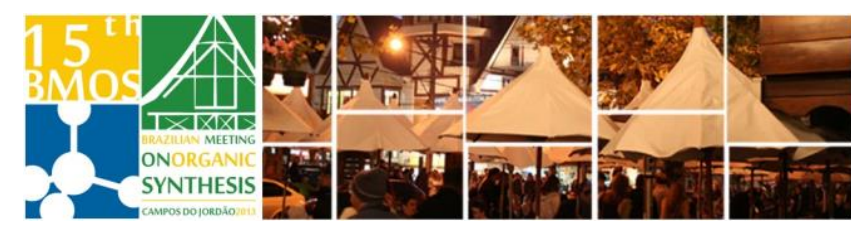

\title{
Electrophilic alkynylation of ketones using hypervalent iodine reagent: a new approach to quaternary carbon formation
}

\author{
Aline Utaka, Lívia N. Cavalcanti and Luiz F. Silva Jr*. \\ Instituto de Química, USP, CP 26077, CEP 05513-970 São Paulo SP, Brazil \\ aline.utaka@usp.br and *luizfsjr@iq.usp.br
}

Keywords: electrophilic alkynylation, quaternary carbon, hypervalent iodine reagent

\section{INTRODUCTION}

Acetylenes have been vastly utilized as intermediates in organic synthesis. Most commonly employed alkynylation method involves the use of nucleophilic alkynylating reagents. However, the use of metal catalysts often leads to undesired homocoupled side product formation diminishing the utility of these protocols. Over the past years, electrophilic alkynylating reagents have emerged as an alternative to the existing methods. Nonetheless, only the $\alpha$-alkynylation of 1,3-dicarbonyl or carbonyls containing strong $\alpha$-electron withdrawing groups were described. ${ }^{1,2}$ Herein, we report a new approach for the $\alpha$-alkynylation of unactivated aromatic ketones using hypervalent iodine reagent.

\section{RESULTS AND DISCUSSION}

We initiated our study using the protocol described for activated ketones with TMS-EBX as alkynyl hypervalent iodine reagent and TBAF as base. ${ }^{2}$ However, we found that for some substrates, TBAF was not a suitable base and only starting material was recovered under these conditions (Table 1, entries 2-4). After extensive optimization, where an array of bases, concentrations, order of addition and temperature were investigated, we determined that the use of potassium tert-butoxide was efficient to afford the desired products in good to excellent yields. Double alkynylation was observed for substrates bearing only hydrogens at the $\alpha$-position (Table 1).

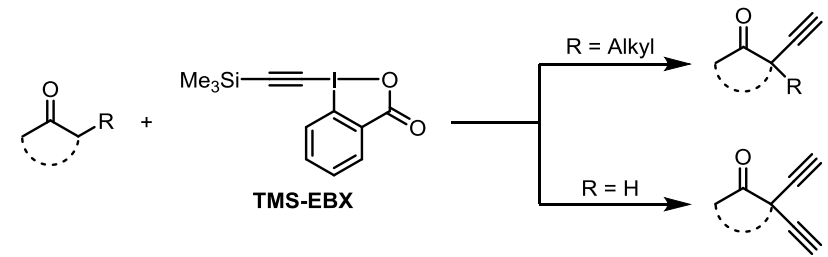

Table 1. Alkynylation of unactivated aromatic ketones.

Entry Substrate

3

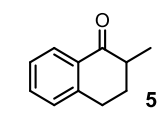<smiles>C#CC1(C)CCc2ccccc2C1=O</smiles>

$0^{[\mathrm{a}][\mathrm{d}]}$ $93^{[\mathrm{b}]}$

4<smiles>O=C1CCCCC1</smiles><smiles>C#CC1(C#C)Cc2ccccc2C1=O</smiles>
$0^{[\mathrm{a}][\mathrm{d}]}$ $80^{[\mathrm{e}]}$ 5<smiles>O=C1CCCCC1P</smiles><smiles>C=CC1(C)CCCCC1=O</smiles>
$85^{[\mathrm{b}]}$<smiles>CCC1C(=O)Cc2ccccc21</smiles><smiles>C#CC1(CC)C(=O)Cc2ccccc21</smiles>
$78^{[\mathrm{b}]}$

7<smiles>O=C1CCCCC1</smiles><smiles>C#CC1(C#C)Cc2sccc2C1=O</smiles>

8<smiles>O=C1C[C@H](S)Cc2c(O)cccc21</smiles><smiles>C#CC(=C)C1(C#C)Cc2c(OC)cccc2C1=O</smiles>

$60^{[\mathrm{c}]}$<smiles>O=C1Cc2ccccc2C[C]1[In]</smiles><smiles>C#CC1(C#C)C(=O)Cc2ccccc21</smiles>
$42^{[\mathrm{c}]}$ 10<smiles>Cc1cc(C)c2c(c1)C(=O)C[C@H]2C</smiles><smiles>C#CC1(C#C)Cc2c(C)cc(C)cc2C1=O</smiles>

$92^{[\mathrm{e}]}$

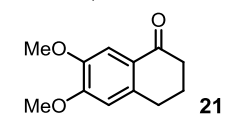

Reaction conditions: ${ }^{[a]}$ substrate $(0.4 \mathrm{mmol}), \operatorname{TMS}-\operatorname{EBX}(1.3 \mathrm{eq})$, $\operatorname{TBAF}(1.3 \mathrm{eq}), \operatorname{THF},-78^{\circ} \mathrm{C}, 2 \mathrm{~h}-3$ days. ${ }^{[b]}$ substrate $(1 \mathrm{mmol}), t^{-}$ BuOk (1.25 eq), TMS-EBX (1.3 eq), TBAF (1.3 eq), THF, $-78^{\circ} \mathrm{C}$, 2-9 h. ${ }^{\mathrm{cc}}$ substrate (1 mmol), $t$-BuOk (2.5 eq), TMS-EBX (2.6 eq), TBAF (2.6 eq), THF, $-78{ }^{\circ} \mathrm{C}, 2-11 \mathrm{~h}$. [d] Starting material recovered. ${ }^{[\mathrm{e}]}$ Method [c] using $t$-BuOk (3 eq) ${ }^{[\mathrm{fl}} 93 \%$ conversion.

\section{CONCLUSION}

We have developed a new method for the $\alpha$ alkynylation of unactivated aromatic ketones using hypervalent iodine reagent TMS-EBX. The results demonstrate the applicability of this reaction and a new approach to quaternary carbon formation.

\section{ACKNOWLEDGEMENTS}

FAPESP, CNPq and CAPES for financial support.

\section{REFERENCES}

${ }^{1}$ Ochiai, M.; Kunishima, M.; Nagao, Y.; Fuji K.; Shiro M. and Fujita, E. J. Am. Chem. Soc., 1986, 108, 8281-8283.

${ }^{2}$ Waser, J.; Brand, J.P. and González, D.F. Chem. Eur. J. 2010, 16, $9457-$ 9461. 